\title{
Administrative Legal Support of Outer Space Activities of the Federative Republic of Brazil
}

\author{
Roman Mkrtchian
}

Ph.D. in Law, Associate Professor, Kherson Institute of Interregional Academy of Personnel Management (Kherson, Ukraine)

E-mail: mroman1985@ukr.net

https://orcid.org/0000-0001-7524-7401

\begin{abstract}
Anna Tkachuk
Ph.D. in History, Associate Professor, Kherson Institute of Interregional Academy of Personnel Management (Kherson, Ukraine)

E-mail: tai3107@ukr.net

https://orcid.org/0000-0002-7473-490X
\end{abstract}

\section{Zhanna Udovenko}

Ph.D. in Law, Borys Grinchenko Kyiv University (Kyiv, Ukraine)

E-mail: z.udovenko@kubg.edu.ua

https://orcid.org/0000-0002-4100-0723

The Federative Republic of Brazil is a progressive country that meets international standards of space law, has the necessary natural conditions for space exploration (lies near the equator and around the ocean) and seeks to develop international mechanisms for cooperation in the peaceful uses of outer space. In this regard, the experience of the Federal Republic of Brazil in legal support of outer space activities is a hotly debated issue among the states that develop the space industry.

Keywords: space activities, law, legal regulation, Brazil, programme, space policy

Received: October 21, 2019; accepted: November 27, 2019

Advanced Space Law, Volume 4, 2019: 59-67.

https://doi.org/10.29202/asl/2019/4/6

\footnotetext{
(C) Mkrtchian, Roman, 2019

(C) Tkachuk, Anna, 2019

(C) Udovenko, Zhanna, 2019
} 


\section{Introduction}

Since the late 1950s, space has become another dramatic arena for countries to prove their technological superiority, military firepower and, by extension their political-economical system. Argentina and Brazil started the first space activities in 1961 and 1967, respectively, with the launch of Alfa-Centauro and Sonda I rockets. Since then, individual South American countries have been developing space capacity to provide basic space-based services and small autonomy in this area. As the countries in the South American region develop their activities, the most significant steps have been initiated by such countries as Brazil, Argentina, Peru and Bolivia. Brazil currently has a well-established institute of space research, has sent one astronaut to the ISS, and continues efforts to develop its own launch capability [Sarli at al., 2018].

The disasters that are occurring in outer space (space debris, collision and fall of cosmic bodies, etc.) require joint efforts of modern States. The development of international cooperation in space activities is an extremely important area for the legal regulation of the space industry. Independent space law institutions can improve their own space infrastructure and create new, individual or general space projects by studying the peculiarities of legal support of outer space activities of an individual state.

Replying to a question "why the experience of the Federal Republic of Brazil is sufficiently important for the space industry", it should be noted that Brazil is the largest Latin American country located near the equator and the ocean. In this light, it is worth stressing that such geographical location makes it possible to carry out space research with minimal risk to humanity. The Federative Republic of Brazil is conducting operations for economic stabilization and is supporting infrastructure industries, including the space one.

The peculiarities of space law in Brazil are the constant attempts to meet the requirements of international norms and high standards of progressive foreign countries.

Thus, the Federative Republic of Brazil is a progressive country that meets international standards of space law, has the necessary natural conditions for space exploration (lies near the equator and around the ocean) and seeks to develop international mechanisms for cooperation in the peaceful uses of outer space. In this regard, the experience of the Federal Republic of Brazil in legal support of outer space activities is a hotly discussed issue among the states that develop the space industry.

The main objective of the article is to analyze the experience of the Federal Republic of Brazil in legal support of outer space activities.

\section{International instruments governing Brazil's space activities}

Since space law is an international public law, it can be inferred that international legislation is a major part of the regulatory framework for Brazil's space activities. According to Brazilian scientist Rodrigo Gómez, as far as the first actors in the exploration and use of outer space were the USSR and the United States, space law originated as a branch of international public law. In a few decades, space law has become a more complex industry, sometimes affecting other branches of law, such as private international law, environmental law, criminal law, and so on. Clearly, like any other field of law, the study of the sources of international space law is of paramount importance [Gomes, 2019].

A treaty that forms the basis of international space law is the Treaty on Principles Governing the Activities of States in the Exploration and Use of Outer Space, including the Moon and Other Celestial Bodies (Tratado sobre os Princípios que Regem as Atividades dos Estados na 
Exploração e Utilização do Espaço Sideral, Incluindo a Lua e Outros Corpos Celestes) or the Outer Space Treaty (Tratado do Espaço Sideral). The space treaty has been ratified by Brazil and most modern countries. Moreover, no country has ever opposed this treaty, what shows its importance to modern humanity [Resolution, 2019].

The Outer Space Treaty (Tratado do Espaço Sideral) represents the basic principles of the conduct of space activities and use of space, namely: the exploration and use of outer space should be carried on for the benefit of all peoples; outer space is not subject to national appropriation by claim of sovereignty, by means of use or occupation, or by any other means; States Parties to the Treaty undertake not to place in orbit around the earth any objects carrying nuclear weapons or any other kinds of weapons of mass destruction; States Parties to the Treaty shall regard astronauts as envoys of mankind in outer space; States Parties to the Treaty shall bear international responsibility for national activities in outer space; States Parties to the Treaty shall pursue studies of outer space, including the moon and other celestial bodies, and conduct exploration of them so as to avoid their harmful contamination [Resolution, 2019].

Consequently, after the adoption of the Outer Space Treaty, it became necessary to codify the rules of space law as a branch of international public law.

The codification of international space law has formed a number of uniform standards for implementation of space activities contained in the following, ratified by Brazil, international instruments: Agreement on the Rescue of Astronauts, the Return of Astronauts and the Return of Objects Launched into Outer Space; The Convention on International Liability for Damage Caused by Space Objects; The Convention on Registration of Objects Launched into Outer Space; Agreement governing the Activities of States on the Moon and Other Celestial Bodies; Declaration of Legal Principles Governing the Activities of States in the Exploration and Use of Outer Space; Principles Relating to Remote Sensing of the Earth from Outer Space; Principles Governing the Use by States of Artificial Earth Satellites for International Direct Television Broadcasting; Principles relevant to the Use of Nuclear Power Sources in Outer Space; The Declaration on International Cooperation in the Exploration and Use of Outer Space for the Benefit and in the Interest of All States, Taking into Particular Account the Needs of Developing Countries [Direito, 2012].

\section{National space laws and regulations governing the conduct of space activities}

In addition to the international norms, the principles of space activities in Brazil are determined by national law, which includes:

- the 1988 Federal Constitution;

- Law No.13.243 of January 11, 2016, "On the civil and legal basis for the regulation of science, technology and innovation";

- Law No.10.973 of December 2, 2004, "Incentive to innovation and scientific and technological research in production";

- Spatial Fund, Law No.9.994 of July 24, 2000. Telecommunications Technology Development Fund;

- Law No. 9.610 of February 19, 1998, "On copyright and related rights";

- the Industrial Property Law No. 9,279 of May 14, 1996;

- the Inter-ministerial Commission for the Export Control of Sensitive Goods, created by Law No. 9.112 of 10 October 1995; 
- "Law Establishing the Brazilian Space Agency" Law No.8.854 of February 10, 1994;

- the National Fund for Scientific and Technological Development, confirmed by Law No. 8.172 of January 18, 1991 [Legislação, 2019].

At the same time, subsidiary laws and decrees of the President of the Republic, interdepartmental decrees, inter-ministerial decrees (Ministries of Science, Technology and Innovation, Ministry of Defense), regulations of the Brazilian Space Agency and normative instructions play a significant role.

In other terms, the legal framework for space activities of the Federative Republic of Brazil consists, first and foremost, of international laws that define most of the standards for outer space resources exploitation and also national legislation, which in turn formulates space management policy and establishes various scientific and technology development programmes.

Furthermore, national legislation in the space sector is adopted by a number of government authorities with different legal status.

\section{Public space administration bodies}

The general competence in matters of legal regulation of space activities in Brazil have such authorities as the Cabinet of Ministers, which determines future development policy in the country; the President of the Republic, who establishes the legal status of government authorities; the Ministry of Defense, which controls the conduct of space activities in Brazil.

The Ministry of Science, Technology, Innovation and Communication is the civilian cabinet organization established to coordinate science, technology, and innovation activities in the country [Institucional, 2019].

In order to expand its field activities, the Ministry of Science, Technology, Innovation and Communication continues to establish the research units and agencies, whose mission is to guarantee and promote the advancement of science, technology, innovation and communication [Institutional, 2019].

Legal regulation of private actors in outer space is defined by the Brazilian Space Program (Program Espacial Brasileiro - PEB), formed as a national development project which is made up of three systems:

1. Target - the National Policy for the Development of Space Activities (Política Nacional de Desenvolvimento das Atividades Espaciais - PNDAE).

2. Institutional - the National System for the Development of Space Activities (Sistema Nacional de Desenvolvimento das Atividades Espaciais - SINDAE).

3. Instrumental - the National Program of Space Activities (Programa Nacional de Atividades Espaciais - PNAE).

Brazil is seeking to ensure its independence in the space sector through the National Policy for the Development of Space Activities approved by Presidential Decree No. 1.332, of December 8, 1994. The policy itself establishes the objectives and the guidelines that shall guide the actions of the Brazilian Government aimed at development of Space Activities of national interest [Política, 2019; Legislação, 2019].

The general objective of the National Policy for the Development of Space Activities (PNDAE) is to advance the capacity of the country, according to appropriate criteria, to utilize 
space techniques and resources in the solution of national problems and in benefit to Brazilian society [Política, 2019].

Generally speaking, the National Program of Space Activities follows the guidelines of the National Policy for the Development of Space Activities, i.e:

1. Provision of assistance to scientific and technological missions;

2. Involvement of highly trained technicians and specialists in all areas of space technology;

3. Formation of research institutions;

4. Promotion of the industrial sector, including the development of automated production;

5. Attraction of investment in the space industry.

Given the multidisciplinary and inter-institutional nature of the Brazilian Program of Space Activities, space activities in Brazil are developed within the framework of the National System for the Development of Space - SINDAE, which was set up by Decree №. 1.953, of 10 July, 1996 [Sistema, 2016; Legislação, 2019].

In Brazil, the concept of a "space development system" is enshrined in legislation, namely the National System for the Development of Space (O Sistema Nacional de Desenvolvimento das Atividades Espaciais - SINDAE) is defined as a group of member organizations responsible for organizing and carrying out space activities aimed at space development of national interest [O que, 2013].

More to the point, the central coordination agency of the National System for the Development of Space is the Brazilian Space Agency (AEB), which reports to the Ministry of Science, Technology and Innovation (MCTI), and is responsible for formulating and coordinating the implementation of the Brazilian space policy [AEB, 2019].

It is worth highlighting, the Brazilian Space Agency is in charge of updating the National Policy for the Development of Space Activities and controlling the National Program of Space Activities. The Superior Council of the AEB is composed of ministries and other governmental agencies involved in space activities, as well as representatives of the Scientific Community and the Industrial Sector [Sistema, 2016].

The following executive bodies constitute the SINDAE: the National Institute for Space Research (Instituto Nacional de Pesquisas Espaciais - INPE); the Department of Aerospace Science and Technology (Departamento de Ciência e Tecnologia Aeroespacial - DCTA); representatives of the industrial sector; universities and research institutes [AEB, 2019].

The main tasks of the National Space Research Institute are fostering scientific research and technological applications, qualifying personnel in the fields of space and atmospheric sciences, space engineering and space technology, as well as climate monitoring and weather forecasting [Sistema, 2016].

In fact, the Brazilian Department of Aerospace Science and Technology is the national military research center subordinated to the Brazilian Air Force, which carries out research and development of launch vehicle systems and related technologies, through its Institute of Aeronautics and Space. The Department of Aerospace Science and Technology (DCTA), under the Ministry of Defence, is gathering a large contingent of highly qualified military and civil servants, including engineers, researchers and technicians [Sistema, 2016].

With a view to increasing the number of students involved in space activities and projects, Brazil provides the learners with six aerospace engineering courses designed by leaders in the field [Sistema, 2016]. 
It should be noted that the mechanism of planning the Brazilian Space Program is implemented through the National Program of Space Activities (PNAE), which contains a set of strategic guidelines, directives and major space missions. The current National Program of Space Activities is in the fourth edition and covers the period 2012-2021 [Programa, 2018].

The National Program of Space Activities is based on three main strategic directions:

1. Society;

2. Autonomy;

3. Industry.

In this regard, in order to meet the needs of society, emphasis is placed on the development of space applications and techniques that address various national problems. The attendant needs cover the areas of telecommunications, the use of natural resources, environmental change observations, sea and border surveillance, weather and climate forecasting, disaster response and promotion of social inclusion [Programa, 2018].

The second problem concerning autonomy lies in the construction and creation of technical, scientific and technological projects in space. Practice has shown that developing solutions to specific domestic problems implies the need to build and develop technological capacity for the production of space-based satellite navigation systems and missile vehicles capable of placing these satellites in orbit [Programa, 2018].

The industry issue requires the reform of the Brazilian production sector with a view to fostering participation and competitiveness in the market for space goods and services. To this end, manpower training, fostering innovation and productivity, as well as technological learning are essential to the progress of industry [Programa, 2018].

More importantly, the National Program of Space Activities defines policy instruments, which are based on: (1) the development of social skills, namely the recruitment of highly qualified personnel in space science, the improvement of social, environmental and information policies with the purpose of meeting all the basic needs of society; (2) the development of space science and technology to create a well-functioning competitive market and independently resolve domestic issues; (3) stimulating partnership projects: entrepreneurial, national, international (between different states and international organizations) to attract investment and develop space activities.

\section{Space educational activities}

Space has demonstrated a remarkable power to inspire widespread interest in science and technology. Therefore, education activities in the space sector is an integral part of space research in every country. In particular, Communication, Navigation, Surveillance, and Air Traffic Management has conducted several training, scientific and technology development programmes. In the light of these experiences, the E2T platform: Education, Space and Technology was conceived as a collection of different programs acting on different stages in the TRL scale. The purpose of the E2T platform is to stimulate interest in space, find talented people and to disclose the existence of national space program to children and the young. The platform aims to promote space workshops, distribute training material, create partnerships and to attract personnel to the space sector [E2T, 2018].

In 2003, the Brazilian Space Agency created the AEB School Programme, which came to be perceived as a viable way of making space science more attractive to young people. The programme is aimed at disseminating knowledge on space activities and at building awareness 
within society as to the importance and the benefits of space activity, in order to encourage the development of space-related research activities and to educate future generations. To assist teachers in developing methodologies for inclusion of these themes in the classroom, the programme offers courses, lectures and workshops. The AEB School Programme was established, along with the cycle of conferences named "Space Thursdays", thematic exhibitions of the Space Program and, in the future, technical courses in partnership with universities. All these activities put Brazilians in direct contact with the everyday life of space science and technologies, in addition to increasing the knowledge of Brazil's achievements in space. [Espaço, 2018].

The following are the tools for the implementation of the AEB School Programme: (1) space travel - the Astronomy Olympiad conducted in partnership with the National Institute for Space Research and the Department of Aerospace Science and Technology; (2) Young SBPC - the annual event for high school students; (3) one-week courses for teachers that include space topics [Espaço, 2018].

The Space Technological Vocational Center (Centro Vocacional Tecnológico Espacial CVT-Espacial) is an initiative of the Brazilian Space Agency (AEB) with the support of the Ministry of Science, Technology, Innovation and Communications (MCTIC). Space CVT brings together different methodologies and tools that are harmoniously integrated with each other, thus contributing to the acquisition of knowledge and skills in the space industry. The Space Technological Vocational Center carries out learning activities that are focused on the dissemination of knowledge on space activities and at building awareness within society. Moreover, the center provides training for technical staff, promotes the social adaptation and qualification of teachers, students and other professionals in the field of space activities [Centro, 2018].

In aggregate, educational and technological programs of the space industry in Brazil are focused on all segments of the population - from schoolchildren and students to adults (teachers, engineers, technicians, astronauts, etc.). The goal is to encourage participation in space activities and to develop competence in new technologies.

The process of space development leads to the emergence of new relations of different kinds, which need to be regulated and regimented. Since space activities can cause damage entailing liability and need for reimbursement for damages, the enforcement of liability in international space law acquires special significance [Muraviov at al., 2019].

The success of Europe in space, following the success of the U.S. and the former U.S.S.R., motivated South America nations to institute long-term space technology efforts for both space access and utilization. World Bank data shows that Brazil has the strongest internal market in South America.

Today, space access is available to virtually any nation willing to purchase a launch, and competitively offered by more than eight nations who are able to provide a launch vehicle for payload delivery. Launch suppliers today include U.S., Russia, Ukraine, China, Japan, India, ESA-member countries (France and Italy), and several additional nations are following closely behind with their own government-sponsored launch vehicles. One of the biggest challenges for South America is undoubtedly to develop a launching site. Launch providers include governments and corporations located on three of the seven continents of the world (North America, Europe, and Asia), and are the product of aggressive R\&D from national space agencies. Both new and derivative models of launchers have evolved according to individual nation's space policies and strategies. Their respective launch sites are located close 
to the Equator on land, coastal areas, and even on the ocean itself. One of the objectives of Brazil is to promote a better integration between space agencies South America. The region has experienced an important amount of democratic stability and social progress, which is a consequence, among other factors, of the benefits resulting from the political coordination among the countries [Sarli et al., 2018].

\section{Conclusions}

In reaching the conclusion, it is necessary to briefly canvas the following systems of the Brazilian Space Program: target, institutional and instrumental.

The target system establishes the objectives and the guidelines that shall guide the actions of the Brazilian Government aimed at development of Space Activities of national interest, and furthermore, implements the consequent actions.

The institutional system consists of the following executive bodies: the Brazilian Space Agency (AEB) — acting as a central organization; the National Institute for Space Research — INPE; the Department of Aerospace Science and Technology; the Brazilian aerospace industry; the National Space Research Institute; educational institutions. The sectoral executive entities of SINDAE are in charge of coordinating the formulation of proposals for the revision of the PNDAE and of elaborating and revising the PNAE, as well as of implementing, causing to implement and follow the actions of the Programme. In all, they provide support to space activities, namely the development, testing and operation of satellites and launch vehicles, including the research activities set forth by the Program.

The instrumental component is identified by the programs, procedures, forms and methods used by space sector stakeholders in the implementation of space policy. The basic instruments used in pursuing space activities are: management techniques; procedures for the formation and implementation of educational and technological programs on space-related topics; procedures aimed at recruiting highly qualified personnel and at advancing science and technology; the conduct of scientific events, preparation and implementation of technology projects and strategies that foster sustainable development; promotion of domestic, national and international partnerships; attraction of investment in the space sector; development of competitive market and industrial policy in the country.

The Federative Republic of Brazil is provided with all conditions necessary for the development of the space industry: favourable geographical location, natural conditions, coherent national space policy and legal support system. Nevertheless, the current process of economic stabilization in the country and lack of investment in the space industry caused the backwardness of national space activities at the international level.

As a final note, this paper concludes that administrative legal support of outer space activities of the Federative Republic of Brazil is highly developed, the national space policy is stable, hence investments into the space sector along with international cooperation will have a positive effect on space exploration.

\section{References}

AEB. Agência Espacial Brasileira, 2019. http://www.aeb.gov.br/institucional/sobre-a-aeb/ Centro Vocacional Tecnológico Espacial. Agência Espacial Brasileira, 2018. http://www.aeb. gov.br/espaco-educacao-e-tecnologia/centro-vocacional-tecnologico/ 
Direito Espacial. Agência Espacial Brasileira, 2012. http://portal-antigo.aeb.gov.br/direitoespacial/

E2T. Agência Espacial Brasileira, 2018. http://www.aeb.gov.br/espaco-educacao-etecnologia/e2t/

Espaço Educação. Agência Espacial Brasileira, 2018. http://www.aeb.gov.br/espacoeducacao-e-tecnologia/espaco-educacao/

Gomes, Rodrigo S. F. Fontes de Direito Espacial Internacional. JusBrasil, 2019. https:// driigomes.jusbrasil.com.br/artigos/685836206/fontes-de-direito-espacialinternacional?ref=serp

Legislação. Agência Espacial Brasileira. 2019. http://www.aeb.gov.br/acesso-a-informacao/ legislacao-2/

Institucional. Ministério da Ciência, Tecnologia, Inovações e Comunicações, 2019. http:// www.mctic.gov.br/mctic/opencms/institucional/paginaInstitucional.html

Muraviov, Kyrylo, Serhii Didenko and Roman Mkrtchian. Liability in International Space Law. Advanced Space Law, Volume 3, 2019: 71-82. https://doi.org/10.29202/as1/2019/3/6

O que é o Sistema Nacional De Atividades Espaciais (SINDAE)? Agência Espacial Brasileira, 2013. http://portal-antigo.aeb.gov.br/o-que-e-o-sistema-nacional-de-atividadesespaciais-sindae/

Política Nacional de Desenvolvimento das Atividades Espaciais (PNDAE). Agência Espacial Brasileira, 2019. http://www.aeb.gov.br/programa-espacial-brasileiro/ politica-organizacoes-programa-e-projetos/politica-nacional-de-desenvolvimento-dasatividades-espaciais-pndae/

Programa Nacional de Atividades Espaciais. Agência Espacial Brasileira, 2018. http://www. aeb.gov.br/programa-espacial-brasileiro/politica-organizacoes-programa-e-projetos/ programa-nacional-de-atividades-espaciais/

Resolution Adopted by the general Assembly 2222 (XXI).Treaty on Principles Governing the Activities of States in the Exploration and Use of Outer Space, including the Moon and Other Celestial Bodies. United Nations Office for Outer Space Affairs, 2019. http:// www.unoosa.org/oosa/en/ourwork/spacelaw/treaties/outerspacetreaty.html

Sarli, Bruno Victorino and all. Review of Space Activities in South America. Journal of Aeronautical History, 2018. https://www.researchgate.net/profile/Brehme_De_ Mesquita2/publication/327970898_Review_of_Space_Activities_in_South_America/ links/5bd07e7c45851537f597aea4/Review-of-Space-Activities-in-South-America.pdf

Sistema Nacional de Desenvolvimento das Atividades Espaciais. Agência Espacial Brasileira, 2016. http://www.aeb.gov.br/programa-espacial-brasileiro/politica-organizacoesprograma-e-projetos/sistema-nacional-de-desenvolvimento-de-atividades-espaciais/ 